\title{
Tourist Village Development Penta Helix Based the Analytical Hierarchy Process Approach
}

\author{
Danang Wahyudi \\ Faculty of Economics and \\ Business, Janabadra University \\ Yogyakarta, Indonesia \\ danangwahyudi@janabadra.ac.id
}

\author{
Erni Ummi Hasanah \\ Faculty of Economics and \\ Business, Janabadra University \\ Yogyakarta, Indonesia \\ erni_uh@janabadra.ac.id
}

\author{
Arif Zulkarnain \\ Binus Business School \\ Jakarta, Indonesia \\ arief.zulkarnain@binus.edu
}

\begin{abstract}
This study identifies the partnership pattern carried out by the Gunung Api Purba tourist village in Nglanggeran Patuk Gunungkidul. Collaboration with multiple stakeholdersis conceptualized in the Penta Helix model. The realization of a synergistic and collaborative partnership will certainly advance the tourism village to be competitive in the global market.
\end{abstract}

We use primary and secondary data in our investigations. The Analytical Hierarchy Process approach is used to support collaborative decisions in the Penta helix model collaboration.

We conclude that the Local Government plays a key role in the Pentahelix cooperation pattern with a result value of 0.447 . The Second is the Community with a value of 0.165 then the third order is academics with a value of 0.139. The fourth-order is business actors with a value of 0.139 and finally the role of the Media with a value of 0.105. Furthermore, policy patterns that can be implemented to develop Gunung Api Purba Tourism Village Area consist of (1) Regulation and Supervision have the highest value 0.234; (2) promotion and information distribution of 0.218 ; (3) provision of employment 0.211 ; (4) active participation in a tourist environment of 0.194; (5) scientific studies and training of human resources with a value of 0.142 .

Keywords: Tourist village, Penta Helix Model, Analytical Hierarchy Process

\section{INTRODUCTION}

Tourismis a sector that has the potential to be developed as a source of regional income. To increase local revenue, the program for the development and utilization of regional tourism resources and potential is expected to make a real contribution to regional economic development. Tourism is a multidimensional activity in a series of development processes. According[1], the development of the tourism sector involves socio-cultural, economic, and political aspects. The development of the tourism sector involves socio-cultural, economic, and political aspects.

In 2013, the government of Gunungkidul Regency is targeting the number of tourist visits as many as 1 million. Finally, the target was exceeded by the number of tourist visits of $1,334,482$ people, with the acquisition of PAD of IDR $6,118,756,600$. The development of tourist visits after that has increased (before the Covid-19 pandemic in March 2020). Data on the development of tourist visits in 2018 and 2019 shows a significant increase from $3,040,095$ to $3,267,497$ people. The increasing number of tourist visits will contribute to PAD which is very important for regional development.
In Gunungkidul Regency, the success of bringing tourists to various tourist destinations is supported, especially from beach tourism objects and tourism objects managed by the community or community, namely tourism villages. In general, this tourist village offers a variety of natural beauty ranging from mountains, hills, rivers, canyons, caves, and also the socio-culture of the local community including handicrafts from each tourist village which has its characteristics and uniqueness. Periodically and regularly, various kinds of cultural attractions are presented in tourist village which is exposed at certain times, such as the celebration of independence day, harvest, Eid Mubarak and so on.

One of the interesting tourist destinations in the Gunung Kidul area which is now a favorite destination is the Gunung Api Purba Tourism village area located in Nglanggeran village. Gunung Api Purba is part of Mount Sewu which is a mountain cluster that stretches from Gunung Kidul Yogyakarta, Wonogiri, Central Java to Pacitan, East Java. Gunung Api Purba is the only mountain in Yogyakarta that was formed from freezing magma that occurred approximately 60 million years ago. Gunung Api Purba has beautiful and exotic landscapes, therefore this area was opened for tourism in 2001 as an ecotourism area.

The development of tourist villages in Gunungkidul district shows that the enthusiasm of community concern for the environment and also the desire to improve economic welfare is getting better. Gunung Api Purba tourist village has received an award as the best Tourism Village I in Indonesia and received the ASEAN Community Based Tourism Award in 2017. However, towards this success, it turns out that some problems are still found in the tourist village. These obstacles, among others (1) tourism management has not been carried out optimally because it is done in a simple and straightforwardly way; (2) have not applied technology to support convenience for tourists; (3) inadequate infrastructure and various supporting facilities and (4) lack of cooperation from other parties outside the tourist village.

To support the development of a competitive tourist village, requires the cooperation of various parties, either directly or indirectly. This condition is also supported by government regulations in the Regional Tourism Development Master Plan (RIPPDA) 2014-2025. In RIPPDA Chapter III, article 7, paragraph 2, emphasizes that the direction of regional tourism industry development policies is to strengthen tourism business partnerships. Problems identification are (1) What is the form of a synergistic partnership pattern in tourism 
management to develop Gunung Api Purba Tourism Village?; (2) What is the form of participation and policies from the Pentahelix partnership pattern in the Gunung Api Purba Tourist Village?

\section{LITERATURE REVIEW}

\section{A. Tourism Village: Its essence, character, and development principles}

Referring to several statements, it means that a tourist village leads to a form of a residential area located in rural areas and has become an area that is a destination for tourist visits because it has an attraction or a tourist attraction, and in this village, tourists can carry out overnight activities[2]. [3]states that a tourist village is a form of settlement with environmental facilities that are by following the demands of tourists to enjoy, know and appreciate or study the uniqueness of the village with all its attractions. By following with the demands of community life activities (including residential activities, social interactions, local customary activities, and so on), to create an environment that is harmonious, recreational, and integrated with the environment.

[4]states that a tourism village is an integration between attractions,accommodation, and supporting facilities that are presented in a structure of community life that integrates with prevailing customs and traditions. She emphasized that the concept is important in the tourism village component; namely accommodation as a residence forresidents, and attractions as the whole daily life of the local population along with the physical setting of the village location that allows tourists to integrate as active participation, such as; dance, language and other courses of a specific nature. Those who travel because they want to get to the countryside with all its components, that is the main attraction [5].

Rural nature has the impression of being a spacious place, fresh air, and a peaceful atmosphere. Besides, several things that attract tourists to visit rural areas, among others, because they want to enjoy the village atmosphere, a different lifestyle and rhythm of life, the impression of freedom and freedom, closeness to nature, farming activities, cultural events, traditional ceremonies., adventure, and togetherness with rural communities, and the friendliness of villagers.

\section{B. Tourism Village Character}

This study was developed based on the community-based tourism (CBT) approach [6];[7]CBT is considered capable of being one of the solutions for the development of environmentally friendly tourism. This tourism model provides a role for the community and is involved in the development process, from ideas, planning, implementation, management, to utilization. Related to this, it is necessary to prepare mature human resources so that the active participation process runs well so that the role of the community becomes real. Community-based tourism opens up opportunities to optimize the social, cultural, and economic potential of the community to balance the role of large-scale tourism businesses in multinational corporate networks. Although it tends to be small and medium scale, the role of CBT needs to be placed in the context of global community cooperation. An equal relationship between tourists and hosts can be developed more deeply so that a sustainable partnership relationship can emerge.

Based on observations in the field, the character of a tourist village that has been formed based on different main attractions can be developed. As shown in the following table:

Table 1. Tourism Village Character And Criteria

\begin{tabular}{|c|c|}
\hline Character & Criteria \\
\hline \multirow{7}{*}{$\begin{array}{l}\text { Village with } \\
\text { Natural } \\
\text { Environment }\end{array}$} & Beautiful nature \\
\hline & $\begin{array}{l}\text { Dominant natural resources as a unique } \\
\text { attraction }\end{array}$ \\
\hline & Still intact \\
\hline & The air is clean and cool or beautiful \\
\hline & $\begin{array}{l}\text { The community is open to tourism } \\
\text { activities }\end{array}$ \\
\hline & It is well known to tourists \\
\hline & Accessibility is relatively adequate \\
\hline \multirow{6}{*}{$\begin{array}{l}\text { Village with } \\
\text { economic life as a } \\
\text { livelihood }\end{array}$} & $\begin{array}{l}\text { Citizens' economic activities as an } \\
\text { attraction }\end{array}$ \\
\hline & $\begin{array}{l}\text { There are relatively no unemployed } \\
\text { residents }\end{array}$ \\
\hline & $\begin{array}{l}\text { The community is open to tourism } \\
\text { activities }\end{array}$ \\
\hline & $\begin{array}{l}\text { Relative economic equality has been } \\
\text { enjoyed by all citizens }\end{array}$ \\
\hline & It is well known to tourists \\
\hline & Accessibility is relatively adequate \\
\hline \multirow{5}{*}{$\begin{array}{l}\text { Village with } \\
\text { traditional life, } \\
\text { art, and culture } \\
\text { that is still thick }\end{array}$} & Preserved artistic and cultural activities \\
\hline & The unique life of local residents \\
\hline & $\begin{array}{l}\text { The community is open to tourism } \\
\text { activities }\end{array}$ \\
\hline & It is well known to tourists \\
\hline & Accessibility is relatively adequate \\
\hline \multirow{7}{*}{$\begin{array}{l}\text { Village with } \\
\text { traditional } \\
\text { buildings }\end{array}$} & $\begin{array}{l}\text { There are still many buildings with } \\
\text { specific local architecture }\end{array}$ \\
\hline & $\begin{array}{l}\text { the existence of a typical village spatial } \\
\text { structure }\end{array}$ \\
\hline & $\begin{array}{l}\text { Landscape patterns and use of local } \\
\text { materials }\end{array}$ \\
\hline & Use of the interior, equipment of local life \\
\hline & $\begin{array}{l}\text { The community is open to tourism } \\
\text { activities }\end{array}$ \\
\hline & It is well known to tourists \\
\hline & Accessibility is relatively adequate \\
\hline
\end{tabular}

C. Pentahelix Synergy Cooperation Pattern Policy

The Pentahelix concept is one of the offers from the Ministry of Tourist related to tourist development in Indonesia. As stated in the Regulation of the Minister of Tourism of the Republic of Indonesia No. 14 of 2016 concerning Guidelines for Sustainable Tourist Destinations. The goal is to ensure and quality activities, facilities, services and create experiences and value for tourism benefits [8]. The relationship between various 
stakeholders in forming Pentahelix cooperation can be described in the image below:

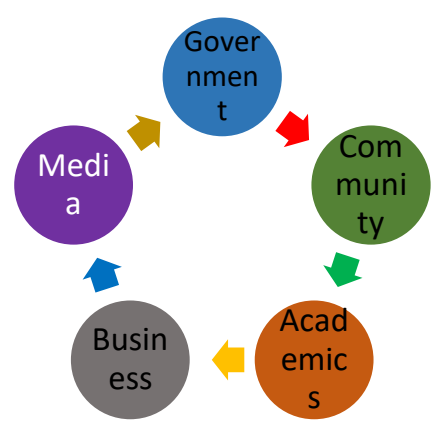

Fig. 1. Penta Helix Cooperation Pattern in the tourist sector

Stakeholders referred to in the Pentahelix Concept in the tourist sector can be explained as follows:

Pillar 1: local government and related agencies in Gunung Kidul have a very vital role because they are related to determining tourism regulations.

Pillar 2: Academics who have a strategic role in helping to contribute knowledge and training needed by local communities.

Pillar 3: Business Actors also have a very big share in advancing tourist areas. The role of business actors is needed in developing superior tourism, especially for marketing local handicraft products.

Pillar 4: Communities where they participate in developing tourist areas as a major role.

Pillar 5: The media can play an active role by participating in smoothing the communication process between stakeholders.

\section{Framework}

In determining the right and ideal Penta helix cooperation pattern to be implemented to develop the Gunung Api Purba Tourist Village area, a framework of thought is drawn up which is described as follows:

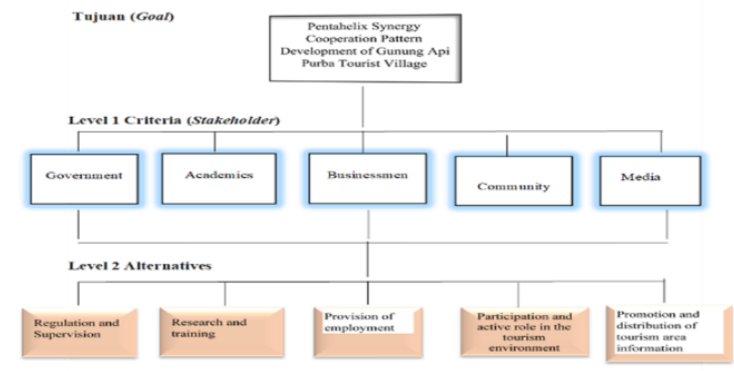

Fig.2. Reseach Framework

\section{RESEARCH METHODS}

\section{A. Population and sample}

The population in this study are key persons who form the Pentahelix collaboration in the tourist village of Gunung Api Purba Nglanggeran Patuk Gunungkidul. These stakeholders include government, business people, academics, communities, and the media. For sampling using non-probability sampling with purposive sampling approach, namely the sampling technique with certain considerations. The selection of a group of subjects in purposive samplingis based on certain characteristics that are considered to have a close relationship with the characteristics of the population that have been previously known. in other words, the sample unit contacted is adjusted according to certain criteria applied based on the research objectives or research problem.

\section{B. Data Collection}

The data used for this research is a combination of primary data and secondary data. Primary data was obtained by conducting interviews and in-depth discussions with selected respondents. Primary data includes the results of extracting information from stakeholders who oversee and are related either directly or indirectly to the management and development of the Gunung Api Purba tourist area. These stakeholders are representatives of the five important elements (Pentahelix) who are considered sufficiently expert and understand the problems. Stakeholders namely are government elements, academics, representatives of business actors, community representatives, and elements of the media.

\section{Key Experts}

In research using the Analytical Hierarchy Process, key experts are selected namely, people who are directly involved in realizing tourism development with the Pentahelix concept. The criteria established as benchmarks for researchers in selecting informants include: (1) Have information about the conditions and characteristics in the Gunung Api Purba tourist Village Area; (2) Having knowledge about the development of a tourist area using Pentahelix; (3) Have the opportunity and are willing to be questioned. The informants selected in this study were stakeholders in the Gunung Api Purba Tourist Area as follows;

Table 2. Stakeholders in the Gunung Api Purba Tourist

\begin{tabular}{|l|l|l|l|}
\hline No & Nama & Jabatan & Unit Kerja \\
\hline 1 & Antonius & Agency secretary & $\begin{array}{l}\text { Dinas } \\
\text { Pariwisata } \\
\text { Gunung Kidul }\end{array}$ \\
& $\begin{array}{l}\text { Hary } \\
\text { Sukmono, MT }\end{array}$ & & $\begin{array}{l}\text { Sekolah Tinggi } \\
\text { Pariwisata } \\
\text { AMPTA }\end{array}$ \\
\hline 2 & $\begin{array}{l}\text { Dra Enny } \\
\text { Mulyantari, }\end{array}$ & $\begin{array}{l}\text { Lecturer and } \\
\text { researcher }\end{array}$ & $\begin{array}{l}\text { Pokdarwis } \\
\text { Desa } \\
\text { Nglanggeran }\end{array}$ \\
\hline 3 & Mursidi & Pokdarwis & $\begin{array}{l}\text { Koran Bernas } \\
\text { online }\end{array}$ \\
\hline 4 & Suwarjono & $\begin{array}{l}\text { Mass media } \\
\text { journalist }\end{array}$ & $\begin{array}{l}\text { Homestay di } \\
\text { Nglanngeran }\end{array}$ \\
\hline 5 & Ibu Sri & Entrepreneur & \multicolumn{2}{|l}{}
\end{tabular}

D. Analysis Tools

Analytical Hierarchy Process (AHP) is an analytical method used to observe complex decisions using mathematical and psychological approaches or human perception. Also, this method is used to be able to organize information and various decisions rationally (judgment) to choose the most preferred alternative.

The basic concept of AHP is the use of a pairwise comparison matrix to produce relative weights between criteria and alternatives. One criterion will be compared with other 
criteria in terms of how important it is to the achievement of the objectives above. Furthermore, pairwise comparisons are made between alternative decisions for each factor to obtain the relative importance between alternatives for each factor. Furthermore, pairwise comparisons are made between alternative decisions for each factor to obtain the relative importance between alternatives for each factor.

\section{Table 3. Pairwise Comparison Rating Scale}

\begin{tabular}{|c|l|}
\hline $\begin{array}{c}\text { Intensity } \\
\text { of } \\
\text { Interest }\end{array}$ & \multicolumn{1}{|c|}{ Explanation } \\
\hline 1 & $\begin{array}{l}\text { The two elements are equally important (Equally } \\
\text { preferred) }\end{array}$ \\
\hline 3 & $\begin{array}{l}\text { One element is slightly more important than the } \\
\text { other (Moderately preferred) }\end{array}$ \\
\hline 5 & $\begin{array}{l}\text { One element is more important than the other } \\
\text { (Strongly preferred) }\end{array}$ \\
\hline 7 & $\begin{array}{l}\text { One element is clearly more absolutely essential } \\
\text { than other elements (Very strongly preferred) }\end{array}$ \\
\hline 9 & $\begin{array}{l}\text { One element is absolutely more important than the } \\
\text { other elements (Extremely preferred) }\end{array}$ \\
\hline $2,4,6,8$ & $\begin{array}{l}\text { The values between the two values of the } \\
\text { considerations are closest }\end{array}$ \\
\hline
\end{tabular}

Source : [9]

The intermediate values namely $2,4,6$, and 8 illustrate the relationship of importance between the odd values mentioned. The intermediate values namely 2, 4, 6, and 8 illustrate the relationship of importance between the odd values mentioned. For example, the pairwise comparison between criteria 1 and 3 is $1 / 5$, meaning that criterion 3 is more important than criterion 1.

\section{RESULTS AND DISCUSSION}

A. The analytical tool used in this study is the Expert Choice V.11 software. The steps in calculating data are as follows:

- Incorporating all the elements that are the goals in the study including the goals, criteria, and alternatives into a hierarchical structure.

- Enter the value comparison of importance for each pair of elements which includes: Comparison matrix between criteria and goal elements, between each criterion and criterion element, and comparison between each criterion element against each alternative element

- Perform synthesis calculations to get the priority order of the alternatives (by calculating the eigenvector value for each matrix).

- Calculating CR (Consistency Ratio)

Measurement of the consistency ratio (Consistency Ratio) by looking at the consistency index. The expected consistency is near perfectto produce a decision that is close to valid. Although it is difficult to achieve a perfect fit, the expected consistency ratio CR $\leq 0.10$. If $\mathrm{CR} \leq 0.10$ then the degree of consistency is satisfactory. If CR> 0.1 then there is inconsistency when setting the pairwise comparison scale. Consistency must be maintained so that the resulting solution is optimal.
B. After calculating using Expert Choice V.11 software, the results of each element are obtained as follows:

- Stage of Forming a Hierarchical Structure

After all, the elements of the research are entered into the software which consists of elements of goals (objectives), criteria, and alternatives.

- Pairwise Comparison Matrix

The second step is to calculate the value comparison of interests for each pair of elements which includes:

comparison between criterion elements, comparison between alternative elements, comparison of each criterion element to alternatives. Then the calculation results are obtained as follows:

- Pairwise Comparison Calculation Between Elements Criteria:

$$
\text { Model Name: KUESIONER PENTAHELIX }
$$

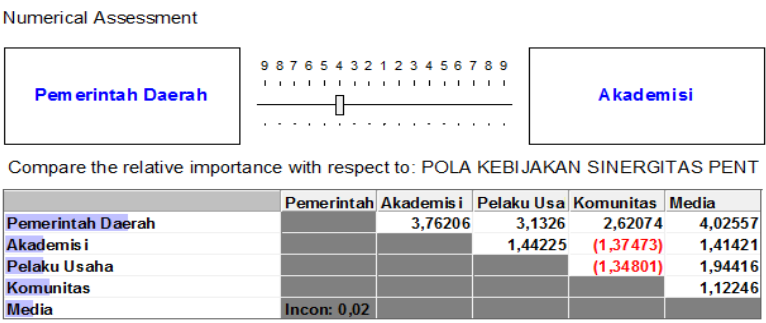

Fig. 3. Pairwise Verbal Comparison concerning to goal

The results of data processing using Expert Choice V.11 show the value obtained for pairwise comparisons with other criteria elements, the results are:

- if the Regional Government is compared to academics having a score of 3.76206; (2) Government and Business 3,1326; (3) Government and Community have a value of 2.62074, (4) Government and Media have a value of 4.02557. Then for: (1) Academics in comparison with Business have a value of 1.44225 ; (2) Academics with the Community have a score of 1.37473 ; (3) Academics with Media have a score of 1.41421 .

- The way to read the table is to compare the elements in the vertical column to the elements in the horizontal column. And so on, with an inconsistency ratio value of 0.02 , it shows that the calculation of the Analytical Hierarchy Process (AHP) for pairwise comparison between criterion elements is acceptable because the consistency ratio value is less than 0.1 .

- Pairwise Comparison Results Between Each Alternative Element with Criteria Elements using Pairwise Numerical Comparison. 
MOdeI Name: KUESIONER PENTAHELIX

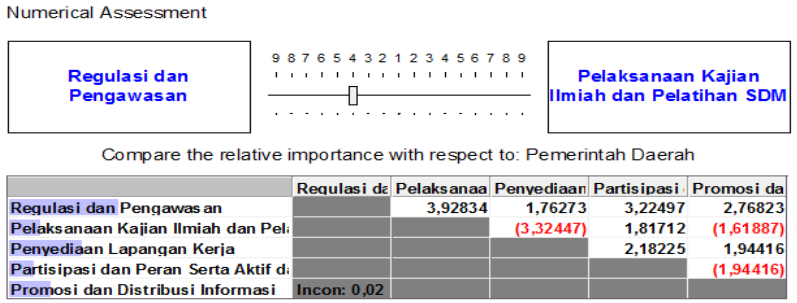

Fig.4. Pairwise Comparison Results Between Criteria Elements of "Local Government" with each Alternative Element (Pairwise Numerical Comparison)

The results of the pairwise comparison (Pairwise Comparison) of the criteria for Local Government elements show the value with each of the alternative

The result is (1) Regulation and Supervision compared to research and HR training has a value of 3.92834; (2) Then Regulation and Supervision is carried out if a pairwise comparison is carried out with the Provision of Employment of 1.76273. The way to read the image is by comparing the elements in the vertical column to the elements in the horizontal column. And so on, with an inconsistency ratio value of 0.02 , it shows that the calculation of the Analytical Hierarchy Process (AHP) for paired criteria between criterion elements is acceptable because the consistency ratio value is less than 0.1 .

The result of the pairwise comparison shows the value obtained for the pairwise comparison of the academic criteria element with each of the alternative elements.

The results are as follows: (1) Regulation and Supervision compared to the Implementation of Scientific Studies and HR Training has a value of 3.16228; (2) Then Regulation and Supervision if a pairwise comparison is carried out with the Provision of Employment of 1.955516. The way to read the image is by comparing the elements in the vertical column to the elements in the horizontal column. And so on, with an inconsistency ratio value of 0.02 , it shows that the calculation of the Analytical Hierarchy Process (AHP) for the pairwise criteria between the Academic criteria element and each of the alternative elements is acceptable because the consistency ratio value is less than 0.1 .

For a pairwise comparison (Pairwise Comparison) of the criteria elements of a Business Actor with each of the alternative elements.

The results are as follows: (1) Regulation and Supervision compared to the Implementation of Scientific Studies and HR Training has a value of 1.7818; (2) Then Regulation and Supervision, if done pairwise comparisons with the Provision of Employment of 3,45044. The way to read the table is to compare the elements in the vertical column to the elements in the horizontal column. And so on, with an inconsistency ratio value of 0.04 , it shows that the calculation of the Analytical Hierarchy Process (AHP) for the paired criteria between the Business Actor's criteria elements with each of the alternative elements is acceptable because the consistency ratio value is less than 0.1 .
For a pairwise comparison (Pairwise Comparison) the Community criteria elements with each of the alternative elements.

The results are as follows: (1) Regulation and Supervision compared to Research and HR Training has a value of 1.91712; (2) Then Regulation and Supervision if a pairwise comparison is carried out with the Provision of Employment of 1.12246. The way to read the table is to compare the elements in the vertical column to the elements in the horizontal column. And so on, with an inconsistency ratio value of 0.04 , it shows that the calculation of the Analytical Hierarchy Process (AHP) for the paired criteria between Community criteria elements and each of the alternative elements is acceptable because the consistency ratio value is less than 0.1 .

For pairwise comparison (Pairwise Comparison) elements of the Media criteria with each of the alternative elements.

The results are as follows: (1) Regulation and Supervision compared to HR Research and Training has a value of 1.0; (2) Then Regulation and Supervision if a pairwise comparison is carried out with the Provision of Employment of 2.33482. The way to read the table is to compare the elements in the vertical column to the elements in the horizontal column. The inconsistency ratio value of 0.02 indicates that the calculation of the Analytical Hierarchy Process (AHP) for the paired criteria between Community criteria elements with each alternative element is acceptable because the consistency ratio value is less than 0.1 .

Perform synthesis calculations to get the priority order of the available alternatives (calculate the eigenvector value for each matrix) Priorities derive from Pairwise Comparison

Model Name: KUESIONER PENTAHELIX

$$
\text { Synthesis: Summary }
$$

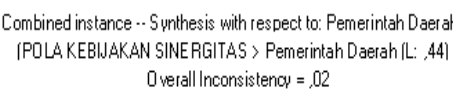

Requlasi dan Penqawasan

Penvediaan Lapanaan Keria

Promosi dan Distribusi Informasi

Pelaksanaan Kailan Ilmiah dan Pelatihan SDM

Partisipasi dan Peran Serta Akktif dalam Lingkunaan Wis at

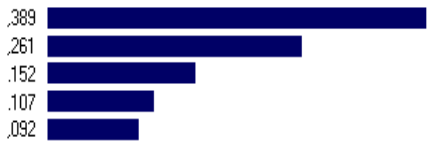

Fig.5. Synthesis Results of Alternative Elements "Local Government" Against Each Alternative Element

The result of the partial synthesis for the Regional Government shows that (1) the most priority policy to be carried out is the Regulation and Supervision policy of 0.389 ; (2) the second policy is the Provision of Employment with a value of 0.261 ; and (3) Participation and Active Participation in the Tourism Environment has the lowest value of 0.092 . The overall inconsistency value is 0.02 . 
Model Name: KUESIONER PENTAHELIX

Synthesis: Summary

Combined instance - S ynthesis with respect to: Akademis

(POLA KEBIJAKAN SINERGITAS > Akademisi IL: 144)II 0 verall Inconsistenoy $=, 02$

Pelaksanaan Kailan Ilmiah dan Pelatihan SDM Promosi dan Distribusi Informasi Partisioasi dan Peran Serta Aktif dalam Linokunaan Wisat Penvedian Panangankia

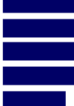

Fig.6. Synthesis Results of Alternative Elements "Academics" Against Each Alternative Element

The result of the partial synthesis for the role of Academics obtained the highest priority scale is the role for the implementation of research of 0.379 , secondly participating in promotion and information distribution activities. With an overall inconsistency value of 0.02 .

The partial results of the synthesis for the role of Business obtained the highest priority scale of the role to participate in providing jobs with a value of 0.402 then the second is to participate and actively participate in the Tourist Environment with a value of 0.237 . With an overall inconsistency value of 0.04 .

The result of the partial synthesis for the role of the community obtained the highest priority scale is participating and active participation in the Tourist Environment with a value of 0.456 then the second is participating in carrying out promotional activities and information distribution with a value of 0.233 . With an overall inconsistency value of 0.01 .

The result of partial synthesis for the role of media obtained the highest priority scale is participating in promotion and distribution of information with a value of 0.486 then the second is participating and playing an active role in the Tourism Environment with a value of 0.189 . With an overall inconsistency value of 0.02 .

Thorough Synthesis of the Criteria Elements of Objective For the pairwise comparison value of each alternative against fellow alternative elements, namely Local Government, Academics, Communities, Business Actors, and the Media, the results of the synthesis are as follows:

The overall synthesis results for the priority scale The criteria elements for the main objectives show that in the Pentahelix Synergy Pattern in developing Gunung Api Purba tourist village Area are as follows: the role of the Regional Government has the greatest value, namely 0.447 ; second place in the Community has a value of 0.165 ; then the third place is academics having a value of 0.139 ; followed by business actors with a value of 0.139 and the fifth or last place is the role of the Media with a value of 0.105 .

The consistency ratio value in this calculation is 0.02 . With a consistency ratio value of 0.02 , it shows that the calculation of the Analytical Hierarchy Process (AHP) for the paired criteria between goal elements is acceptable because the consistency ratio value is less than 0.1 .

\section{Objectives}

Comprehensive Synthesis of Alternative Elements of

The result of the overall synthesis of Alternative elements towards the main objective, namely how the Pentahelix Synergy Policy Pattern in developing Gunung Api Purba tourists village Area shows that:

Regulation and Supervision has the highest score, namely 0.234 ; (2) then promotion and information distribution of 0.218 ; (3) provision of employment of 0.211 and (4) active participation and participation in the tourism environment of 0.194; (5) conducting research and human resources with a value of 0.142

The inconsistency ratio value of 0.02 indicates that the calculation of the Analytical Hierarchy Process (AHP) for priority between the alternative elements to the goal is acceptable because the consistency ratio value is less than 0.1 .

\section{CONCLUSIONS AND SUGGESTIONS}

\section{A. Conclusions}

The tourism industry, as a significant contributor to regional income in Gunung Kidul district, is often less than optimal in driving the economic sector. One of them is the lack of coordination among various stakeholder elements. The role of the government in tourism development is expected to be able to provide facilities in the development of tourism in Gunung Kidul district in general and especially in Gunung Api Purba tourist village in Nglanggeran. The convenience is through policies that can be implemented and able to collaborate with all other stakeholders in the tourist sector. In tourist management and development, coordination and collaboration are needed between the government, business, communities, academics, and the media in developing tourism potential.

Results of this study indicate that the local government plays a key role in the Pentahelix cooperation pattern with a value of 0.447 ; second place in the Community has a value of 0.165 ; then the third place is academics having a value of 0.139 ; followed by business actors with a value of 0.139 and the fifth or last place is the role of the Media with a value of 0.105 .

\section{B. Suggestions}

This study has limitations, including the limited number of variations of informants as key persons, where the representative of the Pentahelix model is only represented by one informant for each element. This is because the use of the Analytical Hierarchy Process (AHP) research method cannot apply to a mass number of respondents. It is hoped that in future research, quantitative research can be carried out with other methods and analysis tools with a larger number of respondents and can represent the population so that the results of the study can be compared to produce more valid research.

\section{REFERENCES}

[1] Basyir, Asyar. (2014). Pengaruh Sektor Pariwisata Terhadap Pertumbuhan Ekonomi http://asyharnotes.blogspot.co.id/2014/11/pengaruh-sektor-pariwisataterhadap.html. Diakses pada tanggal 22 November 2017.

[2] Ahima-putra, Heddy Shri., (2000). Pengembangan model pariwisata pedesaan sebagai alternatif pembangunan berkelanjutan, Lembaga Penerbitan UGM

[3] Ikaputra, (2008) People Response Localize, The Impact Culture. In presented at the 14th world conference on erathquakes engineering. http://www.static.monolic.com/

[4] Nuryati, Windu. (1992)."Concept, Perspektive and Challenges". Naskah Lengkap Laporan Konferensi Internasional mengenai Pariwisata Budaya. Yogyakarta: Gadjah Mada University Press

[5] Sharpley, R., \& Sharpley, J. (1997). Rural tourism. An introduction (pp. 1-165). International Thomson Business Press

[6] Häusler, N. and W. Strasdas. (2003). Training manual for communitybased tourism. Zschortau: InWEnt - Capacity Building International

[7] Beeton, S. (2006). Community Development Through Tourism. Collingwood, Australia : Landlinks Press

[8] Yudha, Verry. (2019) Konsep Penta Helix Dalam Pariwisata. Desabisa online diakses melalui https://www.desabisa.com/

[9] Saaty, L. T, (1980),“The Analytic Hierarchy Process", New York: McGraw-Hill 